\title{
KAJIAN KESUBURAN TANAH UNTUK EVALUASI KESESUAIAN LAHAN KAITANNYA UNTUK MITIGASI BENCANA KEKERINGAN DI KABUPATEN NGANJUK
}

\section{SOIL FERTILITY ASSESSMENT FOR EVALUATION OF LAND SUITABILITY FOR MITIGATION RELATED TO DROUGHT IN NGANJUK REGENCY}

\author{
Dyah Nursita Utami ${ }^{1}$ dan Hasmana Soewandita ${ }^{1}$ \\ ${ }^{1}$ Pusat Teknologi Reduksi Risiko Bencana (PTRRB) - BPPT \\ Gedung 820, GEOSTECH, PUSPIPTEK, Kota Tangerang Selatan, telepon: (021) 75791378 \\ e-mail: dyah.nursita@bppt.go.id, hasmana.soewandita@bppt.go.id
}

\begin{abstract}
Nganjuk Regency is a potential agricultural granary. Results fields and plantations is one supporting the needs of farms and plantations in East Java in particular and Java in general. Agricultural production in Nganjuk Regency often experiences fluctuating phases, one of which is due to drought. Assessment of soil fertility for land suitability evaluation into one of the efforts in mitigating drought in Nganjuk. This soil fertility assessment is carried out by taking soil samples based on the unit of land maps. Unit of land maps obtained from the overlay of base maps such as soil type maps, landuse maps, topographic maps and administrative maps of Nganjuk. The results of the laboratory analysis of soil samples subsequently analyzed and interpreted to obtain: 1) soil fertility status in Nganjuk; 2) determine suitability class; 3) determine the characteristics of an influential land for the development of food crops and plantations; 4) obtain recommendations or technologies efforts in tackling drought in Nganjuk.
\end{abstract}

Keywords: Nganjuk, soil fertility, land suitability, drought mitigation

\begin{abstract}
ABSTRAK
Kabupaten Nganjuk merupakan lumbung pertanian potensial. Hasil sawah dan perkebunannya merupakan salah satu penopang kebutuhan pertanian dan perkebunan di Jawa Timur pada khususnya dan Pulau Jawa pada umumnya. Hasil produksi pertanian di Kabupaten Nganjuk sering mengalami fase naik turun salah satunya karena adanya bencana kekeringan. Dalam hal ini kajian kesuburan tanah untuk evaluasi kesesuaian lahan menjadi salah satu upaya dalam mitigasi bencana kekeringan di Kabupaten Nganjuk. Kajian kesuburan tanah ini dilakukan dengan pengambilan sampel tanah berdasarkan peta satuan unit lahan. Peta satuan unit lahan diperoleh dari hasil overlay peta-peta dasar seperti peta jenis tanah, peta jenis penggunaan lahan, peta topografi dan peta administrasi Kabupaten Nganjuk. Hasil analisis sampel tanah dari laboratorium kemudian dianalisis dan diinterpretasikan untuk memperoleh: 1) status kesuburan tanah di Kabupaten Nganjuk; 2) mengetahui kelas kesesuaian lahan; 3) mengetahui karakteristik lahan yang berpengaruh untuk pengembangan tanaman pangan maupun perkebunan; 4) memperoleh rekomendasi upaya atau teknologi yang tepat dalam mengatasi bencana kekeringan di Kabupaten Nganjuk.
\end{abstract}

Kata kunci: Nganjuk, kesuburan tanah, kesesuaian lahan, mitigasi kekeringan

\section{PENDAHULUAN}

\subsection{Latar Belakang}

Kabupaten Nganjuk mempunyai wilayah seluas $1.224,33 \mathrm{~km}^{2}$ yang terbagi menjadi tiga bagian menurut jenis tanah yaitu tanah sawah
(35\%), tanah kering (27\%) dan tanah hutan (38\%). Secara topografi wilayah Kabupaten Nganjuk terdiri dari daerah pegunungan dan dataran rendah, sebagian besar kecamatan di Kabupaten Nganjuk berada di dataran rendah dengan ketinggian antara 46-95 mdpl (Statistik Daerah Kabupaten Nganjuk, 2020). 
Dengan wilayah yang terletak pada dataran rendah dan pengunungan, Kabupaten Nganjuk memiliki kondisi dan struktur tanah yang cukup produktif untuk berbagai jenis tanaman, baik tanaman pangan maupun perkebunan sehingga sangat menunjang pertumbuhan ekonomi di bidang pertanian. Kondisi dan struktur tanah yang produktif ini juga didukung dengan penyediaan air dari 43 sungai yang melewati Kabupaten Nganjuk dan Sungai Brantas yang mampu mengairi sawah seluas $42.918 \mathrm{Ha}$. Dengan potensi ini bidang pertanian di Kabupaten Nganjuk dijadikan leading dari wilayah-wilayah sekitarnya (Statistik Daerah Kabupaten Nganjuk, 2020).

Tapi pada saat musim kemarau tidak semua sungai yang melintasi Kabupaten Nganjuk ini dapat berkontribusi dalam mengairi lahan-lahan yang tersebar di Kabupaten Nganjuk karena mengalami kekeringan, sehingga sering terjadi bencana kekeringan pada beberapa wilayah di Kabupaten Nganjuk. Bencana kekeringan yang terjadi di Kabupaten Nganjuk juga diungkapkan pada kabar berita di Jawa Pos Radar Kediri, 25 Agustus 2020. Kepala BPBD Soekonjono mengungkapkan Kabupaten Nganjuk siaga darurat kekeringan dan kebakaran hutan dan lahan (karhutla). Beberapa desa yang masuk pemantauan BPBD tersebar di beberapa kecamatan mulai Kecamatan Ngepung, Kecamatan Lengkong, kemudian Desa Gampeng, Desa Tempuran dan Desa Lengkonglor, Kecamatan Ngluyu. Ada pula Desa Pule, Kecamatan Jatikalen; Desa Genjeng, Kecamatan Loceret; dan Desa Oro-oro Ombo, Kecamatan Ngetos.

Selain bencana kekeringan yang mengakibatkan sulitnya ketersediaan air bersih untuk kebutuhan sehari-hari, bencana kekeringan juga sangat berdampak pada lahan pertanian dan produktivitasnya di Kabupaten Nganjuk. Salah satu upaya mengatasi kekeringan adalah dengan melakukan kajian kesuburan tanah untuk mengevaluasi kesesuaian lahan. Dengan mengetahui status kesuburan tanah, maka dapat dilakukan analisis evaluasi kesesuaian lahannya. Hasil evaluasi kesesuaian lahan di sini akan terlihat faktor apa yang menjadi pembatas dalam usaha pertanian maupun perkebunan sehingga dapat dilakukan upaya perbaikan atau mitigasi dalam mengatasi faktor pembatas tersebut. Selain tujuan tersebut evaluasi kesesuaian lahan akan membantu dalam penyusunan arahan teknis lahan yang tepat, sehingga penggunaan lahan dapat dimanfaatkan dengan mempertimbangkan potensi masing-masing yang dimiliki oleh setiap lahan.

\subsection{Tujuan}

Tujuan dari kajian ini adalah 1) mengetahui kelas kesuburan tanah; 2) mengetahui kelas kesesuaian lahan; 3) mengetahui karakteristik lahan yang berpengaruh untuk pengembangan tanaman pangan maupun perkebunan; 4) memperoleh rekomendasi upaya atau teknologi yang tepat dalam mengatasi bencana kekeringan di Kabupaten Nganjuk. Hasil penelitian ini dapat dimanfaatkan oleh instansi yang terkait sebagai salah satu upaya penanggulangan bencana kekeringan di Kabupaten Nganjuk.

\section{METODOLOGI PENELITIAN}

\subsection{Lokasi dan Waktu Kajian}

Penelitian ini dilaksanakan di Kabupaten Nganjuk pada tahun 2019. Lokasi pengambilan sampel tersebar di seluruh kecamatan di Kabupaten Nganjuk.

\subsection{Alat dan Bahan}

Alat yang digunakan dalam penelitian ini meliputi: peralatan dasar survei tanah (ring sampel, meteran, cangkul, GPS (Global Positioning System), kompas, Munsel soil colour chart, form isian kesesuaian lahan, kamera, dan seperangkat komputer.

Bahan yang diperlukan dalam pembuatan peta survei Kabupaten Nganjuk, diperlukan petapeta dasar sebagai berikut:
a. Peta jenis tanah
b. Peta jenis penggunaan lahan
c. Peta topografi
d. Peta administrasi

Hasil overlay peta-peta di atas menjadi peta satuan lahan yang akan dianalisis secara spasial untuk menentukan titik samplingnya. Peta ini digunakan selama survei lapangan untuk menggali data primer di Kabupaten Nganjuk.

\subsection{Metode Penelitian}

Metode penelitian dalam kajian di Kabupaten Nganjuk adalah sebagai berikut:

a. Koordinasi dengan instansi terkait Dalam hal ini, koordinasi dilakukan dengan Badan Perencanaan dan Pembangunan Daerah Kabupaten Nganjuk, Dinas Pertanian Kabupaten Nganjuk, dan Badan Penanggulangan Bencana Daerah Kabupaten Nganjuk. Koordinasi ini akan memudahkan pemetaan potensi lahan berdasarkan data yang ada.

b. Pengumpulan data sekunder

Pengumpulan data sekunder ini meliputi studi pustaka data pendukung serta peta-peta dasar yang diperlukan dalam pembuatan peta SPL.

c. Pengumpulan data primer

Metode pengumpulan data secara primer dilakukan melalui survei lapangan dengan peta SPL. Survei lapangan meliputi pengamatan 
karakteristik lahan, pengambilan sampel tanah, serta wawancara kepada petani jika memungkinkan.

d. Analisis laboratorium

Setelah diperoleh sampel tanah di setiap titiktitik pengamatan, maka dilakukan analisis laboratorium untuk setiap parameter kesuburan tanah meliputi variabel-variabel fisik-kimia tanah seperti: tekstur, kadar air, bulk density, permeabilitas tanah, ruang pori total, $\mathrm{pH}, \mathrm{C}$ organik, Nitrogen, Kalium, Fosfor, kation-kation dapat ditukar seperti $\mathrm{Ca}, \mathrm{Mg}, \mathrm{K}, \mathrm{Na}$, Kapasitas Tukar Kation (KTK), dan Kejenuhan Basa (KB), bahan organik, tekstur tanah, dan sebagainya. Analisis tanah dilakukan di Laboratorium ICBB (Indonesian Center for Biodiversity and Biotechnology) Bogor.

e. Analisis data dan Interpretasi

Setelah hasil laboratorium diketahui, maka dilakukan analisis serta interpretasi dari hasil pengamatan dan hasil laboratorium.

f. Evaluasi dan rekomendasi

Dari hasil analisis dan interpretasi data yang telah diperoleh maka dilakukan evalusi dan rekomendasi sesuai dengan tujuan kajian di Kabupaten Nganjuk.

Berikut di bawah satuan peta lahan yang digunakan dalam pengambilan sampel tanah di Kabupaten Nganjuk. Satuan peta lahan diperoleh dari hasil overlay peta-peta dasar yang telah dijelaskan sebelumnya.

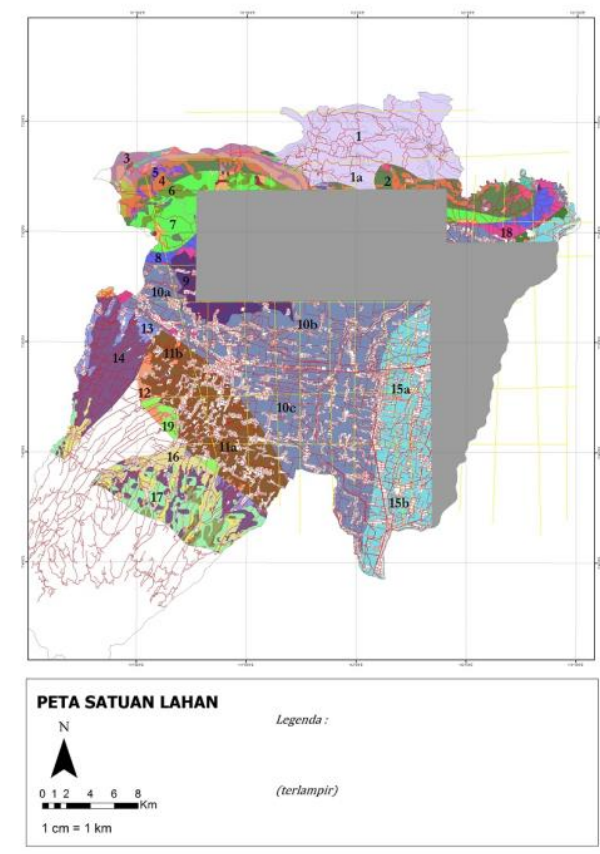

Gambar 1. Satuan Peta Lahan

Kabupeten Nganjuk

\section{HASIL DAN PEMBAHASAN}

\subsection{Kesuburan Tanah}

Kesuburan tanah adalah kemampuan tanah untuk menyediakan unsur hara, dengan takaran dan kesetimbangan tertentu secara berkesinambungan untuk menunjang pertumbuhan suatu jenis tanaman pada lingkungan dengan faktor pertumbuhan lainnya dalam keadaan menguntungkan (Poerwowidodo, 1992). Makin tinggi ketersediaan hara, maka semakin subur pula tanah tersebut dan begitu juga sebaliknya. Kandungan unsur hara dalam tanah selalu berubah-ubah, tergantung pada musim, pengolahan tanah dan jenis tanaman (Rosmarkam dan Yuwono, 2002).

Kesuburan tanah dapat juga diartikan sebagai suatu keadaan tanah dimana tata air, udara, dan unsur hara dalam keadaan cukup seimbang dan tersedia sesuai kebutuhan tanaman, baik fisik, kimia, dan biologi tanah (Effendi, 1995). Keadaan fisika tanah meliputi kedalaman efektif, tekstur, struktur, kelembaban, dan tata udara tanah. Keadaan kimia tanah meliputi reaksi tanah $(\mathrm{pH}$ tanah), KTK, KB, bahan organik, banyaknya unsur hara, cadangan unsur hara dan ketersediaan terhadap pertumbuhan tanaman. Sedangkan biologi tanah antara lain meliputi aktivitas mikrobia perombak bahan organik dalam proses humifikasi dan pengikatan nitrogen udara.

Untuk mengetahui sejauh mana tingkat kesuburan suatu bentang lahan/tanah dapat dilakukan sampling tanah yang diikuti oleh uji tanah di laboratorium. Secara umum uji tanah adalah suatu kegiatan analisis fisik-kimia di laboratorium yang sederhana, cepat, murah, tepat, dan dapat diulang (reproduceable) untuk menduga ketersediaan hara dalam tanah.

\subsubsection{Sifat Fisik}

Sifat fisik tanah meliputi kadar air tanah, tekstur, bulk density, permeabilitas tanah, dan ruang pori tanah. Berikut hasil pengamatan di lapangan serta hasil dari laboratorium untuk sifat fisik tanah di Kabupaten Nganjuk. 
Tabel 1. Hasil Analisis Laboratorium Sifat Fisik Sampel Tanah di Kabupaten Nganjuk

\begin{tabular}{|c|c|c|c|c|c|c|}
\hline \multirow{3}{*}{ No. } & \multirow{3}{*}{$\begin{array}{l}\text { Unit } \\
\text { Lahan } \\
\text { (UL) }\end{array}$} & \multirow{3}{*}{ Desa, Kecamatan } & \multicolumn{4}{|c|}{ Parameter } \\
\hline & & & $\begin{array}{c}\text { Bulk } \\
\text { Density }\end{array}$ & $\begin{array}{l}\text { Particle } \\
\text { Density }\end{array}$ & $\begin{array}{c}\text { Ruang Pori } \\
\text { Total }\end{array}$ & Permeabilitas \\
\hline & & & $g / c c$ & $g / c c$ & $\%$ & $\mathrm{~cm} / \mathrm{jam}$ \\
\hline 1 & UL 1 & Ngadiboyo, Rejoso & 1,12 & 2,19 & 48,78 & 1,33 \\
\hline 2 & UL 2 & Ngumpul, Bagor & 1,15 & 2,20 & 47,62 & 1,12 \\
\hline 3 & UL 3 & Ngadipuro, Wilangan & 1,19 & 2,23 & 46,66 & 1,90 \\
\hline 4 & UL 4 & Gampeng, Ngluyu & 1,02 & 2,11 & 51,76 & 1,83 \\
\hline 5 & UL 5 & Logawe, Lengkong & 1,16 & 1,92 & 39,51 & 3,71 \\
\hline 6 & UL 6 & Gandu, Bagor & 1,19 & 2,07 & 42,56 & 1,85 \\
\hline 7 & UL 7 & Banjaranyar, Tanjunganom & 1,07 & 2,14 & 49,89 & 3,15 \\
\hline 8 & UL 8 & Kampung Baru, Tanjunganom & 1,06 & 2,01 & 47,25 & 3,02 \\
\hline 9 & UL 9 & Jatigreges, Pace & 1,08 & 2,12 & 49,17 & 2,60 \\
\hline 10 & UL 10 & Sukoharjo, Wilangan & 1,09 & 2,08 & 47,66 & 1,83 \\
\hline 11 & UL 11 & Tempuran, Ngluyu & 1,09 & 2.14 & 48.96 & 2,90 \\
\hline 12 & UL 12 & Mojoduwur, Ngetos & 1,13 & 2,25 & 49,87 & 1,86 \\
\hline 13 & UL 13 & Bajang, Ngluyu & 1,12 & 2,22 & 49,63 & 2,70 \\
\hline 14 & UL 14 & Lengkong Lor, Ngluyu & 1,18 & 2,29 & 48,58 & 1,87 \\
\hline 15 & UL 15 & Bajulan, Ngetos & 1,06 & 1,87 & 43,21 & 4,43 \\
\hline 16 & UL 16 & Kedungsoko, Sukomoro & 1,12 & 2,25 & 50,27 & 1,79 \\
\hline
\end{tabular}

Sumber : Hasil Analisis, 2019

Bulk density (BD) merupakan petunjuk kepadatan tanah. Makin padat suatu tanah makin tinggi bulk density berarti makin sulit meneruskan air atau ditembus akar tanaman. Pada umumnya bulk density kurang dari 0,85 (Hardjowigeno, 1981). Bulk density tanah di lokasi sampling menunjukkan nilai $\mathrm{BD}$ yang berkisar antara 1,02 $\mathrm{gr} / \mathrm{cm}^{3}$ hingga $1,19 \mathrm{gr} / \mathrm{cm}^{3}$. Hasil analisis memperlihatkan bahwa tingkat kepadatan tanah di Kabupaten Nganjuk masih tergolong baik. Dikatakan baik karena tanah tersebut masih memiliki tekstur tanah yang kasar. Nilai dengan kisaran $1 \mathrm{gr} / \mathrm{cm}^{3}$ hingga $1,8 \mathrm{gr} / \mathrm{cm}^{3}$ bahwa tekstur tanah tersebut masih tergolong kasar. Kondisi ini disebabkan oleh kemampuan tanah di bawah tegakan yang beraneka ragam (tanaman pangan maupun tanaman perkebunan) dalam meloloskan air (permeabilitas) masih baik sehingga bisa menaikkan laju infiltrasi air.

Secara umum tanah-tanah di lokasi kajian mempunyai fraksi debu lebih tinggi dibandingkan dengan fraksi pasir dan liat. Kandungan fraksi debu antara 67,76\% hingga 98,38\% sehingga berdasarkan kriteria segitiga tekstur, tanah-tanah di lokasi tersebut digolongkan sebagai tanah yang mempunyai tekstur lempung berdebu hingga lempung liat berdebu. Jenis tanah ini memberikan ketersediaan nutrisi, ketersediaan air, udara yang cukup serta sifat-sifat fisik yang baik dimana sistem perakaran tanaman bisa leluasa untuk berkembang.

Ruang pori total adalah volume dari tanah yang ditempati oleh udara dan air. Persentase volume ruang pori total disebut porositas. Untuk menentukan porositas, contoh tanah ditempatkan pada tempat berisi air sehingga jenuh dan kemudian cores ini ditimbang. Perbedaan berat antara keadaan jenuh air dan core yang kering oven merupakan volume ruang pori. Untuk 400 $\mathrm{cm}^{3}$ cores yang berisi $200 \mathrm{gr}\left(200 \mathrm{~cm}^{3}\right)$ air pada kondisi jenuh porositas tanahnya akan mencapai $50 \%$ (Foth, 1988).

Ruang pori total di lokasi studi bervariasi antara $39,51 \%$ yang teridentifikasi di Lengkong hingga yang tertinggi $51,76 \%$ teridentifikasi di Ngluyu. Sebagaimana dijelaskan di atas, tekstur tanah sangat menentukan ruang pori total. Tekstur yang mengandung pasiran tinggi akan lebih kecil ruang pori totalnya apabila dibandingkan dengan tanah yang mengandung liat atau debu yang lebih tinggi.

Permeabilitas tanah menunjukkan kemampuan tanah dalam meloloskan air. Struktur dan tekstur serta unsur organik lainnya ikut ambil bagian dalam menaikkan laju permeabilitas tanah. Tanah dengan permeabilitas tinggi menaikkan laju infiltrasi dan dengan demikian, menurunkan laju air larian. Permeabilitas tanah di lokasi studi bervariasi antara $1,12 \mathrm{~cm} / \mathrm{jam}$ hingga yang tertinggi $4,43 \mathrm{~cm} / \mathrm{jam}$. Permeabilitas terendah teridentifikasi di lahan sawah di Kecamatan Bagor, sedangkan permeabilitas tertinggi teridentifikasi di Kecamatan Ngetos.

\subsubsection{Sifat Kimia}

Sifat kimia tanah yang dianalisis dalam kajian ini antara lain sebagai berikut: 
Tabel 2. Hasil Analisis Laboratorium Sifat Kimia Sampel Tanah di Kabupaten Nganjuk

\begin{tabular}{|c|c|c|c|c|c|c|c|c|c|c|c|c|c|c|c|c|c|c|c|c|}
\hline \multirow{4}{*}{$\begin{array}{l}\text { Unit } \\
\text { Lahan } \\
\text { (UL) }\end{array}$} & \multirow{4}{*}{$\begin{array}{l}\text { Desa, } \\
\text { Kecamatan }\end{array}$} & \multicolumn{19}{|c|}{ Parameter } \\
\hline & & \multicolumn{2}{|c|}{$\mathrm{pH}$} & \multirow{3}{*}{ ن } & \multirow{3}{*}{$\frac{\dot{z} \frac{\bar{g}}{\circ}}{\%}$} & \multirow{3}{*}{$\begin{array}{c}\mathbf{C} / \mathbf{N} \\
\text { Ratio } \\
\# \\
-\end{array}$} & \multirow{2}{*}{$\begin{array}{c}\mathbf{P}_{2} \mathrm{O}_{5} \\
\text { Tersedia }\end{array}$} & \multirow{2}{*}{$\begin{array}{c}\mathrm{P}_{2} \mathrm{O}_{5} \\
\text { Poten } \\
\text { sial }\end{array}$} & \multirow{2}{*}{$\begin{array}{c}\mathrm{K}_{2} \mathrm{O} \\
\text { Poten } \\
\text { sial }\end{array}$} & \multicolumn{4}{|c|}{ Kation Dapat Tukar } & \multirow[t]{2}{*}{ KTK } & \multirow{2}{*}{ KB } & \multicolumn{2}{|c|}{$\begin{array}{l}\text { Kemasaman } \\
\text { Dapat Tukar }\end{array}$} & \multicolumn{3}{|c|}{ Tekstur 3 Fraksi } \\
\hline & & $\mathrm{H}_{2} \mathrm{O}$ & $\stackrel{N}{\mathrm{KCl}}$ & & & & & & & $\mathrm{K}^{+}$ & $\mathrm{Na}^{+}$ & $\mathrm{Ca}^{2+}$ & $\mathbf{M g}^{2+}$ & & & $\mathbf{A l}^{3+}$ & $\mathbf{H}^{+}$ & Pasir & Debu & Klei \\
\hline & & \multicolumn{2}{|r|}{ 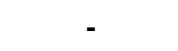 } & & & & $\mathrm{mg} / \mathrm{Kg}$ & \multicolumn{2}{|c|}{$\mathrm{mg} / 100 \mathrm{~g}$} & \multicolumn{5}{|c|}{$\mathrm{cmol}(+) / \mathbf{k g}$} & $\%$ & \multicolumn{2}{|c|}{$\mathrm{cmol}(+) / \mathbf{k g}$} & \multicolumn{3}{|c|}{$\%$} \\
\hline 1 & $\begin{array}{l}\text { Ngadiboyo, } \\
\text { Rejoso }\end{array}$ & 6,09 & 4,17 & 1,86 & 0,15 & 12 & 11,60 & 19,45 & 45.58 & 0,29 & 0,22 & 14,55 & 3,05 & 25,30 & 71,55 & 0,13 & 0,44 & 26 & 27 & 47 \\
\hline 2 & $\begin{array}{l}\text { Ngumpul, } \\
\text { Bagor }\end{array}$ & 7,47 & 6,16 & 3,59 & 0,24 & 15 & 161,66 & 117,87 & $\begin{array}{c}127.1 \\
5 \\
\end{array}$ & 1,35 & 2,27 & 47,72 & 15,37 & 64,29 & 100,00 & 0,00 & 0,36 & 16 & 14 & 70 \\
\hline 3 & $\begin{array}{l}\text { Ngadipuro, } \\
\text { Wilangan }\end{array}$ & 5,99 & 4,48 & 1,10 & 0,07 & 16 & 7,68 & 14,20 & 12.32 & 0,05 & 0,04 & 25,19 & 3,58 & 32,73 & 88,18 & 0,00 & 0,11 & 29 & 28 & 43 \\
\hline 4 & $\begin{array}{l}\text { Gampeng, } \\
\text { Ngluyu }\end{array}$ & 7,29 & 6,61 & 1,20 & 0,10 & 12 & 58,16 & 109,97 & $\begin{array}{c}110.4 \\
0\end{array}$ & 0,55 & 0,34 & 54,26 & 1,48 & 38,43 & 100,00 & 0,00 & 0,23 & 17 & 34 & 48 \\
\hline 5 & $\begin{array}{l}\text { Logawe, } \\
\text { Lengkong }\end{array}$ & 7,66 & 6,37 & 1,57 & 0,11 & 14 & 15,58 & 33,07 & 12.50 & 0,04 & 0,07 & 37,97 & 4,39 & 40,74 & 100,00 & 0,00 & 0,17 & 39 & 15 & 46 \\
\hline 6 & Gandu, Bagor & 7,66 & 6,39 & 3,41 & 0,22 & 16 & 81,46 & 69,90 & 18.78 & 0,15 & 0,82 & 35,86 & 10,60 & 38,96 & 100,00 & 0,00 & 0,18 & 16 & 26 & 58 \\
\hline 7 & $\begin{array}{l}\text { Banjaranya, } \\
\text { Tanjunganom }\end{array}$ & 7,77 & 6,16 & 1,88 & 0,13 & 14 & 120,41 & 98,61 & 85.21 & 0,49 & 0,43 & 26,98 & 11,52 & 40,33 & 97,76 & 0,00 & 0,18 & 12 & 31 & 58 \\
\hline 8 & $\begin{array}{l}\text { Kampung } \\
\text { Baru, } \\
\text { Tanjunganom }\end{array}$ & 7,76 & 6,17 & 1,41 & 0,14 & 10 & 96,82 & 84,71 & 73.77 & 0,42 & 0,58 & 20,62 & 12,84 & 34,54 & 99,79 & 0,00 & 0,24 & 27 & 24 & 49 \\
\hline 9 & $\begin{array}{l}\text { Jatigreges, } \\
\text { Pace }\end{array}$ & 6,97 & 4,97 & 1,13 & 0,09 & 13 & 117,62 & 91,62 & 51.53 & 0,23 & 0,14 & 12,68 & 3,65 & 20,64 & 80,94 & 0,00 & 0,17 & 35 & 31 & 34 \\
\hline 10 & $\begin{array}{l}\text { Sukoharjo, } \\
\text { Wilangan }\end{array}$ & 7,09 & 5,95 & 1,00 & 0,07 & 14 & 143,23 & 88,49 & 44.71 & 0,26 & 0,55 & 25,31 & 8,41 & 34,16 & 100,00 & 0,00 & 0,28 & 20 & 29 & 51 \\
\hline 11 & $\begin{array}{l}\text { Tempuran, } \\
\text { Ngluyu }\end{array}$ & 6,76 & 4,51 & 1,16 & 0,12 & 10 & 208,61 & 103,12 & $\begin{array}{c}113.5 \\
7 \\
\end{array}$ & 0,55 & 0,03 & 42,53 & 5,59 & 47,39 & 100,00 & 0,00 & 0,35 & 23 & 17 & 60 \\
\hline 12 & $\begin{array}{l}\text { Mojoduwur, } \\
\text { Ngetos }\end{array}$ & 6,89 & 5,43 & 2,48 & 0,19 & 13 & 52,57 & 65,34 & 16.17 & 0,18 & 0,25 & 17,17 & 5,99 & 29,28 & 80,56 & 000 & 0,17 & 10 & 36 & 54 \\
\hline 13 & $\begin{array}{l}\text { Bajang, } \\
\text { Ngluyu }\end{array}$ & 7,48 & 6,85 & 2,57 & 0,19 & 14 & 106,92 & 149,91 & $\begin{array}{c}114.0 \\
3 \\
\end{array}$ & 0,40 & 0,11 & 52,46 & 2,53 & 32,05 & 100,00 & 0,00 & 0,34 & 22 & 49 & 30 \\
\hline 14 & $\begin{array}{l}\text { Lengkong Lor, } \\
\text { Ngluyu }\end{array}$ & 8,29 & 7,10 & 0,66 & 0,07 & 9 & 36,98 & 75,33 & 70.62 & 0,12 & 0,09 & 61,98 & 3,67 & 34,67 & 100,00 & 0,00 & 0,35 & 21 & 35 & 44 \\
\hline 15 & $\begin{array}{l}\text { Bajulan, } \\
\text { Ngetos }\end{array}$ & 7,60 & 5,60 & 1,47 & 0,11 & 13 & 60,93 & 96,81 & 85.17 & 0,76 & 0,16 & 9,46 & 3,58 & 14,11 & 98,89 & 0,00 & 0,23 & 50 & 26 & 24 \\
\hline 16 & $\begin{array}{l}\text { Kedungsoko, } \\
\text { Sukomoro }\end{array}$ & 8,20 & 6,78 & 2,46 & 0,14 & 18 & 88,97 & 76,40 & 92.98 & 0,84 & 4,78 & 26,55 & 12,26 & 38,11 & 100,00 & 0,00 & 0,29 & 18 & 26 & 55 \\
\hline
\end{tabular}

Sumber : Hasil Analisis (2019) 
Kondisi $\mathrm{pH}$ tanah hasil analisis laboratorium di 16 lokasi menunjukkan kondisi $\mathrm{pH}$ tanah yang bervariasi antara 6,09 hingga yang tertinggi mendekati netral dengan $\mathrm{pH} 8,29$. Berdasarkan kriteria kualitas kesuburan tanah, $\mathrm{pH}$ tanah di lahan di wilayah Kabupaten Nganjuk relative netral. Hasil analisis laboratorium di beberapa lokasi di areal lahan kering lingkup wilayah Kabupaten Nganjuk, kandungan bahan $\mathrm{C}$ organik bervariasi antara $0,66 \%$ hingga $3,41 \%$. Berdasarkan kriteria kelas kualitas kesuburan tanah, rentang nilai tersebut mempunyai kualitas kandungan $\mathrm{C}$ organik dari rendah hingga sangat tinggi

Kadar $\mathrm{N}$ total tanah wilayah Kabupaten Nganjuk berkisar antara 0,07\% hingga 0,24\%. Berdasarkan kriteria kesuburan tanah kandungan $\mathrm{N}$ total tanah dalam kategori bervariasi dari sangat rendah hingga tinggi. Hasil analisis laboratorium di beberapa lokasi di areal lahan kering lingkup wilayah Kabupaten Nganjuk, kandungan $\mathrm{P}_{2} \mathrm{O}_{5}$ tersedia bervariasi antara 7,68 $\mathrm{mg} / 100 \mathrm{~g}$ hingga 208,61 ppm. Berdasarkan kriteria kelas kualitas kesuburan tanah, rentang nilai tersebut termasuk dalam kualitas yang sedang hingga sangat tinggi. Perbedaan kandungan $\mathrm{P}_{2} \mathrm{O}_{5}$ dalam tanah tentunya tergantung dari bahan induk pembentuk tanah yang berbeda antara yang satu dengan yang lainnnya. Kandungan yang tinggi ini bisa berasal dari bahan batuan pembentuk phospat yang tinggi di wilayah tersebut. Kandungan terendah terdapat di wilayah Kecamatan Wilangan dan kandungan tertinggi berada di wilayah Kecamatan Ngluyu.

Hasil analisis laboratorium di beberapa lokasi di areal lahan wilayah Kabupaten Nganjuk $\mathrm{K}_{2} \mathrm{O}$ tersedia bervariasi antara $12,32 \mathrm{mg} / 100 \mathrm{~g}$ hingga $127,15 \mathrm{mg} / 100 \mathrm{~g}$, serta berdasarkan kriteria kelas kualitas kesuburan tanah mempunyai kualitas kandungan yang sedang hingga sangat tinggi. Kandungan terendah terdapat di wilayah Kecamatan Wilangan dan kandungan tertinggi berada di wilayah Kecamatan Bagor. Kandungan $\mathrm{K}_{2} \mathrm{O}$ tersedia, pada tanah-tanah di wilayah Kabupaten Nganjuk khususnya pada lahan sawah, sehingga upaya-upaya untuk perbaikannya sudah tidak perlu lagi. Sebagaimana diketahui pada tanah yang kandungan $\mathrm{K}_{2} \mathrm{O}$ tersedianya rendah, dapat diupayakan pengelolaannya dengan penambahan pupuk Kalium seperti KCL atau pupuk majemuk NPK.

Kandungan $\mathrm{Na}$ tanah bervariasi antara 0,03 $\mathrm{mg} / 100 \mathrm{~g}$ hingga $4,78 \mathrm{mg} / 100 \mathrm{~g}$. Berdasarkan kriteria kelas kualitas kesuburan tanah, rentang nilai tersebut mempunyai kualitas kandungan yang sangat rendah hingga sedang dan hanya satu lokasi yang mempunyai kandungan yang sangat tinggi. Kandungan terendah terdapat di wilayah Kecamatan Ngluyu dan kandungan tertinggi berada di wilayah Kecamatan Sukomoro.
Kandungan Ca di beberapa lokasi di areal lahan lingkup wilayah Kabupaten Nganjuk bervariasi antara $9,46 \mathrm{cmol} / \mathrm{kg}$ hingga 61,98 $\mathrm{cmol} / \mathrm{kg}$. Berdasarkan kriteria kelas kualitas kesuburan tanah mempunyai kualitas kandungan yang sedang hingga sangat tinggi. Kandungan terendah terdeteksi di Kecamatan Bajulan sedangkan tertinggi terdeteksi di Kecamatan Ngluyu. Meskipun kandungan $\mathrm{Ca}$ dapat ditukar ( $\mathrm{Ca} \mathrm{dd}$ ) tergolong hara esensial sekunder dan berdasarkan fungsi yang sebenarnya juga penting untuk kinerja pertumbuhan, akan tetapi upaya pengelolaan tanah karena $\mathrm{Ca}$ dd (dapat ditukar) sangat rendah sering diabaikan. Secara tidak langsung, upaya perbaikan $\mathrm{pH}$ yang rendah karena tingkat kemasaman tanah yang tinggi, dengan penambahan kapur $\left(\mathrm{CaCO}_{3}, \mathrm{CaO}\right)$ dapat digunakan sebagai upaya perbaikan kandungan Ca dd di dalam tanah.

KTK tanah lahan kering di wilayah Kabupaten Nganjuk sangat fluktuatif, nilainya bervariasi antara $14,11 \mathrm{cmol} / \mathrm{kg}$ hingga $64,29 \mathrm{cmol} / \mathrm{kg}$. Namun demikian secara umum KTK tanah hampir semuanya berada di atas batas sedang dan tergolong tinggi hingga sangat tinggi. Tingkat KTK tanah tertinggi terdapat di Kecamatan Bagor dan terendah terdapat di Kecamatan Bajulan.

Tingkat Kejenuhan Basa (KB) bervariasi antara 71,55\% hingga 100\%. Berdasarkan kriteria kelas kualitas kesuburan tanah, nilai dengan rentang tersebut menunjukkan kualitas tingkat kejenuhan basa antara sangat rendah hingga rendah. Sehingga, secara umum, kondisi tingkat Kejenuhan Basa (KB) yang rendah ini menunjukkan kondisi kesuburan tanah juga rendah.

\subsection{Evaluasi Kesesuaian Lahan}

Kabupaten Nganjuk memiliki potensi sektor pertanian yang baik. Untuk mendukung pengembangan potensi sektor pertanian yang dimiliki Kabupaten Nganjuk, kajian tentang sektor pertanian perlu dilakukan sebagai upaya mengoptimalkan penggunaan lahan secara berkelanjutan. Untuk dapat memanfaatkan sumberdaya lahan secara optimal, terarah, dan efisien, diperlukan data dan informasi kualitas lahan serta kesesuaian lahan.

Kesesuaian lahan adalah kecocokan dari sebidang lahan untuk tipe penggunaan tertentu. Evaluasi kesesuaian lahan dapat dilakukan jika diperoleh data karakteristik lahan. Karakteristik lahan adalah sifat lahan yang dapat diukur atau diestimasi. Karakteristik lahan yang digunakan dalam menilai lahan adalah temperatur rata-rata tahunan, curah hujan (tahunan atau pada masa pertumbuhan), kelembaban udara, drainase, tekstur, bahan kasar, kedalaman efektif, kematangan dan ketebalan gambut, KTK, KB, $\mathrm{pH}$, $\mathrm{C}$ organik, total $\mathrm{N}, \mathrm{P}_{2} \mathrm{O}_{5}, \mathrm{~K}_{2} \mathrm{O}$, salinitas, alkalinitas, kedalaman sulfidik, lereng, batuan di permukaan, 
singkapan batuan, bahaya longsor, bahaya erosi serta tinggi dan lama genangan.

Sistem evaluasi lahan yang berkembang selama ini, menggunakan berbagai pendekatan, antara lain sistem perkalian parameter, penjumlahan, dan sistem matching atau mencocokkan antara kualitas/karakteristik lahan (land qualities/land characteritics) dengan persyaratan tumbuh tanaman, lingkungan, dan manajemen (landuse requirement). Struktur klasifikasi kesesuaian lahan yang digunakan pada dasarnya mengacu pada Framework of Land Evaluation (FAO, 1976) dengan menggunakan 4 kategori, yaitu ordo, kelas, subkelas dan unit. Dalam pemetaan tanah tingkat semi detil, klasifikasi kesesuaian lahan dilakukan sampai tingkat subkelas.

Hasil evaluasi lahan menggunakan prosedur di atas berupa kelas kesesuaian lahan aktual dan kelas kesesuaian lahan potensial. Kelas kesesuaian lahan aktual (actual land suitability) menyatakan kesesuaian lahan berdasarkan data hasil survei tanah atau sumberdaya lahan yang belum mempertimbangkan masukan-masukan yang diperlukan untuk mengatasi kendala atau faktor pembatas hubungannya dengan persyaratan tumbuh tanaman. Lahan tersebut dapat berupa areal yang belum dibuka atau belum diusahakan, atau sudah berupa lahan pertanian, namun belum dikelola secara optimal atau intensif. Dengan memperhatikan kendala yang ada, potensi lahan tersebut masih dapat ditingkatkan.

\subsubsection{Padi Sawah}

Tanaman padi sawah menjadi tanaman pangan yang banyak ditanam di Kabupaten Nganjuk. Tanaman padi sawah menjadi tanaman yang tersebar di seluruh kecamatan di Kabupaten Nganjuk, berdasarkan Kabupaten Nganjuk Dalam Angka 2020, 4 kecamatan mempunyai luas area panen terbanyak selama tahun 2019, yaitu Kecamatan Tanjunganom, Kecamatan Rejoso, Kecamatan Gondang, dan Kecamatan Prambon. Untuk meningkatkan produktivitas padi sawah di seluruh kecamatan, maka diperlukan evaluasi kesesuaian lahan untuk tanaman padi sawah. Hasil evaluasi kesesuaian lahan tanaman padi sawah di Kabupaten Nganjuk, dapat dilihat sebagai berikut:

Tabel 3. Kesesuaian Lahan Tanaman Padi Sawah di Kabupeten Nganjuk

\begin{tabular}{|c|c|c|c|c|}
\hline \multirow{2}{*}{$\begin{array}{c}\text { UL } \\
\text { (Unit } \\
\text { Lahan) }\end{array}$} & \multirow{2}{*}{ Desa, Kecamatan } & \multirow{2}{*}{ Sampel } & \multicolumn{2}{|c|}{ Padi Sawah } \\
\hline & & & Aktual & Potensial \\
\hline UL 1 & Ngadiboyo, Rejoso & NGA 01 & S3oa,na & S2oa,rc,na \\
\hline UL 2 & Ngumpul, Bagor & NGA 02 & S3na & S2oa,nr,na \\
\hline UL 3 & Ngadipuro, Wilangan & NGA $03 \mathrm{~A}$ & S3oa,rc,na & S3rc \\
\hline UL 4 & Gampeng, Ngluyu & NGA 04 & Neh & S3eh \\
\hline UL 5 & Logawe, Lengkong & NGA 05 & Neh & S3rc,eh \\
\hline UL 6 & Gandu, Bagor & NGA 06 & S3oa & S2oa,nr,na \\
\hline UL 7 & Banjaranya, Tanjunganom & NGA $07 \mathrm{~A}$ & S2nr,na & S1 \\
\hline UL 8 & Kampung Baru, Tanjunganom & NGA 08 A & S2nr,na & S1 \\
\hline UL 9 & Jatigreges, Pace & NGA 09 & S3rc,na & S3rc \\
\hline UL 10 & Sukoharjo, Wilangan & NGA 10 & S3na & S2nr,na \\
\hline UL 11 & Tempuran, Ngluyu & NGA 11 & Neh & S3oa,rc,eh \\
\hline UL 12 & Mojoduwur, Ngetos & NGA $12 \mathrm{~A}$ & S2na & S1 \\
\hline UL 13 & Bajang, Ngluyu & NGA 14 & Neh & S3eh \\
\hline UL 14 & Lengkong Lor, Ngluyu & NGA $15 \mathrm{~A}$ & Neh & S3nr,na,eh \\
\hline UL 15 & Bajulan, Ngetos & NGA $16 \mathrm{~A}$ & Neh & S3rc,eh \\
\hline UL 16 & Kedungsoko, Sukomoro & NGA 17 & S3nr & S2nr,na \\
\hline
\end{tabular}

Sumber : Hasil Analisis, 2019

Kesesuaian lahan aktual untuk tanaman padi sawah di berbagai unit lahan menunjukkan kelas kesesuaian lahan bervariasi, mulai dari kelas terendah N (tidak sesuai) sampai kelas S2 (cukup sesuai). Kesesuaian lahan aktual dengan kelas $\mathrm{N}$ (tidak sesuai) untuk tanaman padi sawah terdapat di beberapa unit lahan seperti di Desa Gampeng Ngluyu, Desa Logawe Lengkong, Desa Tempuran Ngluyu, Desa Bajang Ngluyu, Desa Lengkong Lor Ngluyu, dan Desa Bajulan Ngetos. Sedangkan kesesuaian lahan aktual dengan kelas S3 (sesuai marginal) untuk tanaman padi sawah terdapat di unit lahan (UL) 1, UL 2, UL 3, UL 6, UL 9, UL 10, dan UL 16, sedangkan kesesuaian lahan aktual dengan kelas S2 (cukup sesuai) untuk tanaman padi terdapat di UL 7 , UL 8, dan UL 12.

Dari hasil analisis kesesuaian lahan untuk tanaman padi sawah, parameter lahan sebagian besar sudah sesuai untuk pertumbuhan padi sawah. Seperti temperatur rata-rata di Kabupaten Nganjuk berkisar antara $25-26^{\circ} \mathrm{C}$ sehingga 
masuk ke dalam kelas cukup sesuai untuk pertumbuhan padi sawah. Temperatur sangat mempengaruhi perkembangan profil tanah, faktor tersebut menentukan sifat kimia dan sifat fisik di dalam tanah. Temperatur rata-rata yang tinggi cenderung menambah kecepatan pelapukan dan pembentukan liat sehingga kesuburan tanah menjadi optimal untuk pertumbuhan padi sawah.

Selain temperatur, curah hujan juga sangat mempengaruhi perkembangan profil tanah melalui sifat kimia dan sifat fisik tanah. Curah hujan yang tinggi cenderung menambah kecepatan pelapukan dan pembentukan liat dan secara tidak langsung mempengaruhi reaksi tanah. Selain itu juga dapat mengakibatkan pencucian kation basa dari lapisan permukaan tanah ke lapisan tanah yang lebih dalam sehingga $\mathrm{pH}$ tanah akan menjadi masam. Bagi pertumbuhan tanaman curah hujan bertindak sebagai penyedia air tanaman sesuai dengan kebutuhannya.

Berdasarkan data Rencana Tata Ruang Wilayah (RTRW) Kabupaten Nganjuk Tahun 2019-2039 diperoleh bahwa curah hujan rendah di Kabupaten Nganjuk mencapai nilai 800 mm/th, dan mencapai nilai curah hujan tertinggi sampai $3.700 \mathrm{~mm} / \mathrm{th}$. Dari setiap sampel unit lahan yang telah disurvei, memiliki curah hujan berkisar antara 1.400-1.900 mm/th dan 1.900-2.300 $\mathrm{mm} / \mathrm{th}$. Nilai tersebut termasuk curah hujan yang optimal untuk pertumbuhan padi sawah sehingga tidak termasuk sebagai faktor pembatas dalam kelas kesesuaian lahan tanaman padi sawah.

Parameter lahan berikutnya yang penting dalam pertumbuahan padi sawah adalah drainase tanah. Drainase tanah yang baik diperlukan oleh tanaman yang membutuhkan aerasi yang baik seperti padi sawah. Aerasi tanah yang baik menyebabkan di dalam tanah cukup tersedia oksigen. Dengan demikian, akar tanaman mampu menyerap unsur hara dan dapat berkembang dengan baik. Berdasarkan pengamatan di lapangan, drainase tanah menjadi faktor pembatas di beberapa unit lahan, seperti di UL 1, UL 3, dan UL 6. Sampel UL 1 terletak di Kecamatan Rejoso, UL 3 di Kecamatan Wilangan sedangkan UL 6 di Kecamatan Bagor.

Usaha perbaikan yang dapat dilakukan untuk memperbaiki kondisi drainase tanah adalah dengan pemberian bahan organik tanah seperti kotoran kambing, kotoran sapi, seresah organik (jerami padi) ataupun pupuk organik. Dengan pemberian bahan organik tersebut akan memperbaiki kondisi fisik tanah sehingga drainase tanah menjadi optimal untuk pertumbuhan padi sawah. Drainase tanah yang optimal untuk pertumbuhan padi sawah masuk ke dalam kelas agak terhambat dan sedang.

Media perakaran menjadi parameter lahan yang tidak dapat dipandang sebelah mata. Media perakaran yang dimaksud adalah tekstur tanah serta kedalaman tanah. Tekstur tanah sangat berhubungan dengan jenis tanah. Sebagian besar jenis tanah di Kabupaten Nganjuk masuk ke dalam jenis aluvial kelabu dan aluvial coklat ataupun asosiasi keduanya. Sehingga mempunyai tekstur tanah yang halus atau agak halus sehingga masuk ke dalam kelas sangat sesuai (S1) untuk pertumbuhan padi sawah.

Faktor pembatas lain dalam pertumbuhan padi sawah yang ditemukan di beberapa unit lahan adalah retensi hara (nr). Retensi hara di sini meliputi nilai KTK tanah $(\mathrm{cmol})$, kejenuhan basa (\%), $\mathrm{pH} \mathrm{H}_{2} \mathrm{O}$ dan kadar C-organik (\%) di dalam tanah. Dari keempat parameter tersebut, nilai $\mathrm{pH} \mathrm{H}_{2} \mathrm{O}$ menjadi faktor pembatas di unit lahan (UL) 3 di Kecamatan Wilangan, UL 7 di Kecamatan Tanjunganom, UL 8 di Kecamatan Tanjunganom, dan UL 16 di Kecamatan Sukomoro. Sedangkan parameter yang lain masuk ke dalam kelas sangat sesuai (S1) untuk pertumbuhan padi sawah. $\mathrm{pH} \mathrm{H}_{2} \mathrm{O}$ secara berturut-turut di UL 3, UL 7, UL 8, dan UL 16 adalah 5,99 (agak masam), 7,77 (agak alkalis), 7,76 (agak alkalis) dan 8,2 (agak alkalis). Sedangkan rentang nilai $\mathrm{pH} \quad \mathrm{H}_{2} \mathrm{O}$ yang dibutuhkan pertumbuhan padi sawah adalah 5,57,0 .

Nilai derajat keasaman tanah $(\mathrm{pH})$ penting untuk menentukan mudah tidaknya unsur-unsur hara diserap tanaman. Karena itu diperlukan usaha perbaikan untuk mengoptimalkan $\mathrm{pH}$ tanah salah satunya dengan cara pengapuran untuk tanah yang masam seperti di UL 3 , sedangkan di UL 7, dan UL 8 bisa dengan cara penambahan sulfur atau belerang. Selain itu, usaha perbaikan yang bisa dilakukan untuk menetralkan $\mathrm{pH}$ tanah adalah dengan penambahan bahan organik tanah. Penambahan bahan organik di setiap unit lahan tersebut harus disesuaikan tingkat kematangannya sehingga berpengaruh positif untuk menaikkan $\mathrm{pH}$ pada tanah masam dan menurunkan $\mathrm{pH}$ pada tanah alkalis.

Jika pH tanah menjadi optimal maka ketersediaan hara bagi pertumbuhan padi sawah juga tercukupi. Faktor ketersediaan hara (na) ini melingkupi kadar $\mathrm{N}$ total tanah, kadar $\mathrm{P}_{2} \mathrm{O}_{5}$ tersedia, dan kadar $\mathrm{K}_{2} \mathrm{O}$ tersedia. Unsur $\mathrm{N}, \mathrm{P}$, dan $\mathrm{K}$ merupakan unsur makro esensial yang diperlukan dalam pertumbuhan tanaman padi.

Dari hasil analisis faktor pembatas ketersediaan hara ditemukan di sebagian besar unit lahan yang disurvei. Kelas ketersediaan hara di UL 1 di Kecamatan Rejoso, UL 2 di Kecamatan Bagor, UL 3 dan UL 10 di Kecamatan Wilangan, dan UL 9 di Kecamatan Pace, tergolong sangat rendah sehingga masuk ke dalam kelas sesuai marginal (S3). Sedangkan di UL 7, UL 8 di Kecamatan Tanjunganom dan UL 12 di Kecamatan Ngetos tergolong rendah sehingga masuk ke dalam kelas cukup sesuai (S2).

Untuk memperbaiki ketersediaan unsur hara di Kabupaten Nganjuk bisa dilakukan dengan 
pemupukan intensif baik pupuk organik maupun pupuk anorganik seperti pupuk $\mathrm{N}$ (Urea), pupuk $\mathrm{P}$ (SP-36), dan pupuk $\mathrm{K}(\mathrm{KCl})$. Untuk menjaga kualitas lahan maka sebaiknya dipilih pupuk organik yang lebih ramah lingkungan seperti kompos, pupuk kandang ataupun pupuk hijau. Atau dengan cara konvensial lain seperti pengembalian jerami padi ke tanah sawah akan memperbaiki kondisi fisik tanah, meningkatkan kesuburan tanah serta mengurangi terjadinya degradasi tanah. Salah satu pupuk organik yang mampu memperbaiki atau membenahi kondisi fisik dan kesuburan tanah serta mampu meningkatkan kadar $\mathrm{N}$ total dalam tanah adalah pemberian Azolla pinnata. Azolla pinnata merupakan jenis tumbuhan paku air yang hidup di perairan. Seperti halnya tanaman Leguminosae, Azolla pinnata mampu mengikat $\mathrm{N}_{2}$ dari udara karena berasosiasi dengan sianobakteri (Anabaena azollae) yang hidup di dalam rongga daunnya. Kemampuan Azolla pinnata mengikat $\mathrm{N}_{2}$ dari udara berkisar antara 400-500 kg N ha-1 tahun-1. Azolla pinnata berkembang sangat cepat dan dapat menghasilkan biomassa sebanyak 10-15 ton ha-1 dengan $\mathrm{C} / \mathrm{N}$ rasio $12-18$, sehingga dalam waktu satu minggu Azolla pinnata telah terdekomposisi dengan sempurna (Khan, 1983).

Kesesuaian lahan aktual untuk tanaman padi sawah dengan kelas tidak sesuai $(\mathrm{N})$ tersebar di UL 4, UL 5, UL 11, UL 13, UL 14, dan UL 15 dengan faktor pembatas kemiringan lereng. Kemiringan lereng di setiap unit lahan tersebut lebih dari $8 \%$ seperti di UL 4 dan UL 5 yang terletak di Kecamatan Ngluyu dan Kecamatan Lengkong, bahkan di Kecamatan Ngluyu terdapat kemiringan lereng yang mencapai $15-25 \%$ seperti di UL 11, UL 13, UL 14, dan UL 15 di Kecamatan Loceret.
Karakteristik lereng ini berhubungan dengan sifat morfologi lahan. Topografi landai memiliki agregat tanah lebih mantap daripada yang berlereng curam, sebab pada topografi yang berlereng curam sering terjadi erosi sehingga bahan organik yang merupakan perekat-perekat agregat hilang sehingga kemantapan agregat tanah menjadi lemah. Kemiringan yang besar maka kecepatan aliran permukaan serta kekuatan mengikis tanah akan menjadi meningkat. Oleh karena itu, diperlukan usaha perbaikan (improvement). Usaha perbaikan untuk faktor pembatas kemiringan lereng bisa dilakukan dengan pembuatan teras, penanaman sejajar kontur, serta penanaman tanaman penutup tanah sehingga laju erosi dapat diminimalisir.

\subsubsection{Jagung}

Tanaman jagung merupakan tanaman yang banyak ditanam di wilayah Kabupaten Nganjuk. Berdasarkan Kabupaten Nganjuk Dalam Angka 2020, seluruh kecamatan di Kabupaten Nganjuk terdapat area tanaman jagung dengan area terluas terdapat di Kecamatan Tanjunganom, Kecamatan Ngluyu, Kecamatan Loceret, Kecamatan Bagor, Kecamatan Sukomoro, dan Kecamatan Lengkong. Karena itu, diperlukan evaluasi kelas kesesuaian lahan untuk mengidentifikasi potensi dan tingkat kecocokan tanah pada komoditi tanaman jagung, dan mempertimbangkan kesesuaian input yang diberikan dengan faktor pembatas yang ada. Dari hasil matching (pencocokkan) antara syarat tumbuh tanaman jagung dengan karakteristik lahan, diperoleh kelas kesesuaian lahan untuk tanaman jagung sebagai berikut:

Tabel 4. Kesesuaian Lahan Tanaman Jagung di Kabupaten Nganjuk

\begin{tabular}{l|l|l|l|l}
\hline \multirow{2}{*}{$\begin{array}{c}\text { UL } \\
\text { Lahit }\end{array}$} & \multicolumn{1}{|c|}{ Desa, Kecamatan } & \multirow{2}{*}{ Sampel } & \multicolumn{2}{|c}{ Jagung } \\
\cline { 4 - 5 } & & & \multicolumn{1}{|c}{ Aktual } & \multicolumn{1}{|c}{ Potensial } \\
\hline UL 1 & Ngadiboyo, Rejoso & NGA 01 & S3wa,na & S3wa \\
\hline UL 2 & Ngumpul, Bagor & NGA 02 & S3oa & S2wa,oa \\
\hline UL 3 & Ngadipuro, Wilangan & NGA 03 A & S3rc,na & S3rc \\
\hline UL 4 & Gampeng, Ngluyu & NGA 04 & S3wa,eh & S3wa \\
\hline UL 5 & Logawe, Lengkong & NGA 05 & S3wa,rc,na,eh & S3wa,rc \\
\hline UL 6 & Gandu, Bagor & NGA 06 & S3na & S2wa,oa,na \\
\hline UL 7 & Banjaranya,Tanjunganom & NGA 07 A & S3wa & S3wa \\
\hline UL 8 & Kampung Baru,Tanjunganom & NGA 08 A & S3wa & S3wa \\
\hline UL 9 & Jatigreges, Pace & NGA 09 & S3wa,rc,na,eh & S3wa,rc \\
\hline UL 10 & Sukoharjo, Wilangan & NGA 10 & S3na & S2wa,oa,na \\
\hline UL 11 & Tempuran, Ngluyu & NGA 11 & Neh & S3wa,rc,eh \\
\hline UL 12 & Mojoduwur, Ngetos & NGA 12 A & S3wa,na & S3wa \\
\hline UL 13 & Bajang, Ngluyu & NGA 14 & Neh & S3wa,eh \\
\hline UL 14 & Lengkong Lor, Ngluyu & NGA 15 A & Neh & S3wa,nr,na,eh \\
\hline UL 15 & Bajulan, Ngetos & NGA 16 A & Neh & S3wa,rc,eh \\
\hline UL 16 & Kedungsoko, Sukomoro & NGA 17 & S3wa & S3wa \\
\hline
\end{tabular}


Hasil kesesuaian lahan aktual untuk tanaman jagung hanya terbagi menjadi 2 kelas yaitu tidak sesuai (N) dan sesuai marginal (S3). Kesesuaian lahan aktual untuk tanaman jagung di UL 11, UL 13, UL 14, dan UL 15 masuk ke dalam kelas tidak sesuai ( $N$ ) dengan faktor pembatas berupa bahaya kemiringan lereng. Sedangkan sisanya masuk ke dalam kelas sesuai marginal (S3).

Sebagian besar faktor pembatas yang ditemukan dalam kesesuaian lahan untuk tanaman jagung adalah curah hujan seperti di UL 1 di Kecamatan Rejoso, UL 4 di Kecamatan Ngluyu, UL 5 di Kecamatan Lengkong, UL 7 dan UL 8 di Kecamatan Tanjunganom, UL 9 di Kecamatan Pace, UL 12 di Kecamatan Ngetos, dan UL 16 di Kecamatan Sukomoro. Curah hujan terendah dari semua sampel unit lahan sebesar 1400-1900 mm/th, sedangkan curah hujan tertinggi dari semua sampel unit lahan sebesar 1900-2300 mm/th. Dengan rentang nilai curah hujan itu, curah hujan masuk ke dalam kelas sesuai marginal (S3).

Jagung memerlukan banyak air ketika berbunga. Pada masa ini waktu hujan yang pendek diselingi dengan matahari jauh lebih baik daripada hujan terus-menerus. Curah hujan yang tinggi menyebabkan kemantapan tanahnya menurun (lemah), karena air hujan tersebut melarutkan bahan organik dan unsur hara yang berfungsi sebagai perekat tanah agregat dan sebaliknya. Karena faktor pembatas curah hujan berhubungan dengan iklim makro suatu tempat, maka tidak dapat dilakukan usaha perbaikan, hanya saja pemilihan masa tanam bisa menjadi solusi untuk menghadapi faktor curah hujan yang terlalu tinggi bagi tanaman jagung. Sehingga kelas kesesuaian potensial untuk tanaman jagung di UL 1 di Kecamatan Rejoso, UL 4 di Kecamatan Ngluyu, UL 5 di Kecamatan Lengkong, UL 7 dan UL 8 di Kecamatan Tanjunganom, UL 9 di Kecamatan Pace, UL 12 di Kecamatan Ngetos, dan UL 16 di Kecamatan Sukomoro masih masuk ke dalam kelas sesuai marginal (S3) dengan faktor pembatas curah hujan. Untuk parameter iklim lainnya seperti suhu udara, faktor suhu udara di semua lokasi unit lahan mempunyai rentang nilai dari $25-26^{\circ} \mathrm{C}$ sehingga masuk ke dalam kelas sangat sesuai untuk pertumbuhan jagung. Sesuai dengan pendapat Rukmana (1997) suhu optimum untuk pertumbuhan jagung adalah dari $23-27^{\circ} \mathrm{C}$. Suhu panas dan lembab amat baik bagi pertumbuhan tanaman jagung pada periode tumbuh sampai fase reproduktif.

Parameter lahan lain yang menjadi faktor pembatas bagi pertumbuhan jagung adalah ketersediaan air (drainase tanah), media perakaran (tekstur tanah) dan ketersediaan hara (kadar $\mathrm{N}$ total tanah, $\mathrm{P}_{2} \mathrm{O}_{5}$ tersedia, dan $\mathrm{K}_{2} \mathrm{O}$ tersedia) serta bahaya erosi (kemiringan lereng).
Sedangkan parameter seperti retensi hara (KTK tanah, $\mathrm{KB}, \mathrm{pH} \mathrm{H}_{2} \mathrm{O}$, dan $\mathrm{C}$-organik), alkalinitas, dan persiapan lahan (batuan di permukaan dan singkapan batuan) sudah memberikan kelas sangat sesuai untuk tanaman jagung. Untuk meningkatkan kelas kesesuaian lahan naik satu tingkat, diperlukan usaha perbaikan (improvement) terhadap faktor pembatas yang ada.

Berdasarkan pengamatan di lapangan drainase tanah unit lahan 2 di Kecamatan Bagor menunjukkan kelas terlambat, sehingga masuk ke dalam kelas sesuai marginal (S3). Usaha perbaikan yang bisa dilakukan untuk memperbaiki kondisi drainase tanah adalah dengan penambahan bahan organik tanah seperti kotoran sapi, kotoran kambing, serasah organik, kompos ataupun pupuk kandang. Pemberian bahan organik ini akan memperbaiki kondisi fisik tanah sehingga drainase tanah menjadi optimal untuk pertumbuhan jagung. Dari penambahan bahan organik tanah ini tidak bisa memperbaiki kondisi tekstur tanah karena tekstur tanah suatu lahan merupakan hasil dari proses pedogenesis batuan yang dipengaruhi oleh iklim, topografi, batuan induk, organisme, dan waktu.

Berdasarkan pengamatan di lapangan kelas tekstur tanah di Unit Lahan (UL) 3 di Kecamatan Wilangan, UL 5 di Kecamatan Lengkong, dan UL 9 di Kecamatan Pace tergolong agak kasar sehingga menjadi faktor pembatas dalam pertumbuhan jagung dengan kelas sesuai marginal (S3). Dari hasil laboratorium juga menunjukkan bahwa presentasi 3 jenis fraksi tekstur tanah pada unit lahan 3 di Kecamatan Wilangan mempunyai fraksi pasir $29 \%$, debu $38 \%$ dan klei $43 \%$, unit lahan 5 di Kecamatan Lengkong mempunyai fraksi pasir 39\%, 15\%, dan klei $46 \%$, sedangkan di unit lahan 9 di Kecamatan Pace mempunyai fraski pasir 35\%, debu 31\%, dan klei 34\%. Sehingga memang dikatakan tekstur tanah di ketiga unit lahan tersebut sesuai marginal untuk pertumbuhan jagung. Tekstur tanah merupakan faktor pembatas yang sulit diatasi karena berhubungan juga dengan faktor alam yang tidak bisa dipengaruhi oleh manusia secara langsung.

Sedangkan usaha perbaikan yang bisa dilakukan untuk memperbaiki ketersediaan hara bagi tanaman jagung di UL 1, UL 3, UL 5, UL 6, UL 9, UL 10, dan UL 12 adalah pemupukan secara intensif, baik pemupukan anorganik ataupun pemupukan organik. Pupuk anorganik yang dapat digunakan antara lain Urea, SP-36, dan TSP. Dosisnya sesuai dengan kebutuhan pada tanah tersebut. Cara lain yang bisa dilakukan untuk meningkatkan ketersediaan hara di dalam tanah secara ramah lingkungan adalah penambahan bahan organik tanah, seperti penambahan kotoran sapi, kotoran kambing, 
kotoran ayam, kompos, kascing, maupun pupuk kandang. Selain meningkatkan ketersediaan hara di dalam tanah, penambahan bahan organik tanah akan membantu memperbaiki kondisi tanah baik secara fisik, kimiawi maupun biologi.

Purwono dan Purnamawati (2007), menjelaskan bahwa peranan bahan organik terhadap kesuburan tanah antara lain: (1) mineralisasi bahan organik akan melepas unsur hara tanaman secara lengkap $(\mathrm{N}, \mathrm{P}, \mathrm{K}, \mathrm{Ca}, \mathrm{Mg}$, $S$, dan unsur hara mikro lainnya) tetapi dalam jumlah yang relatif kecil; (2) meningkatkan daya menahan air, sehingga kemampuan tanah untuk menyediakan air menjadi lebih banyak; (3) memperbaiki kehidupan mikroorganisme tanah.

Berdasarkan survei lapangan yang telah dilakukan, beberapa unit lahan mempunyai kemiringan lereng berkisar antara 8-15\% sehingga masuk ke dalam kelas sesuai marginal (S3) dan beberapa diantaranya seperti di unit lahan (UL) 11, UL 13, UL 14, di Kecamatan Ngluyu, dan UL 15 di Kecamatan Loceret bahkan mempunyai kemiringan lereng sampai 15-25\% sehingga masuk ke dalam kelas tidak sesuai $(\mathrm{N})$ untuk pertumbuhan tanaman jagung. Seandainya budidaya jagung terus dilakukan maka pengolahan tanah di lahan ini harus berpedoman pada metode konservasi tanah dan air, antara lain dengan mengadakan penanaman jagung searah dengan kontur, pembuatan terasering, penanaman penutup tanah dan usaha lainnya sehingga bahaya erosi bisa diminimalisir. Dengan usaha perbaikan yang telah dilakukan maka kelas kesesuaian lahan potensial di setiap unit lahan untuk tanaman jagung menjadi sesuai marginal (S3) dengan faktor pembatas kemiringan lereng.

\subsubsection{Bawang Merah}

Potensi ekonomi daerah yang dimiliki dan layak dikembangkan oleh Kabupaten Nganjuk salah satunya adalah sektor pertanian. Kontribusi sektor pertanian untuk daerah adalah perannya dalam pembentukan Produk Domestik Regional Bruto (PDRB). Bawang merah menjadi komoditas unggulan pada sektor pertanian yang ikut menyumbang nilai PDRB. Namun kontribusi komoditas bawang merah untuk sektor pertanian belum optimal karena sering mengalami fluktuasi dan di bawah target produksi yang ditentukan. Sehingga, diperlukan langkah pengembangan terhadap komoditas unggulan bawang merah. Salah satunya dengan melakukan evaluasi kesesuaian lahan untuk tanaman bawang merah, sehingga diketahui faktor pembatas dan upaya perbaikannya dalam pengembangan produksi bawang merah di Kabupaten Nganjuk.

Berdasarkan Kabupaten Nganjuk Dalam Angka 2020, produksi bawang merah tertinggi tersebar di Kecamatan Rejoso, Kecamatan Bagor, Kecamatan Gondang, Kecamatan Wilangan, dan Kecamatan Sukomoro. Hasil evaluasi kesesuaian lahan untuk tanaman bawang merah dapat dilihat sebagai berikut:

Tabel 5. Kesesuaian Lahan Tanaman Bawang Merah di Kabupaten Nganjuk

\begin{tabular}{|c|c|c|c|c|}
\hline \multirow{2}{*}{$\begin{array}{c}\text { UL } \\
\text { (Unit } \\
\text { Lahan) }\end{array}$} & \multirow{2}{*}{ Desa, Kecamatan } & \multirow{2}{*}{ Sampel } & \multicolumn{2}{|c|}{ Bawang Merah } \\
\hline & & & Aktual & Potensial \\
\hline UL 1 & Ngadiboyo, Rejoso & NGA 01 & S3wa,na & S3wa \\
\hline UL 2 & Ngumpul, Bagor & NGA 02 & S3wa,oa,na & S3wa \\
\hline UL 3 & Ngadipuro, Wilangan & NGA $03 \mathrm{~A}$ & S3wa,rc,na & S3wa,rc \\
\hline UL 4 & Gampeng, Ngluyu & NGA 04 & S3wa,eh & S3wa \\
\hline UL 5 & Logawe, Lengkong & NGA 05 & S3wa,rc,eh & S3wa,rc \\
\hline UL 6 & Gandu, Bagor & NGA 06 & S3wa & S3wa \\
\hline UL 7 & Banjaranya,Tanjunganom & NGA $07 \mathrm{~A}$ & S3wa & S3wa \\
\hline UL 8 & Kampung Baru,Tanjunganom & NGA 08 A & S3wa & S3wa \\
\hline UL 9 & Jatigreges, Pace & NGA 09 & S3wa,rc,na & S3wa,rc \\
\hline UL 10 & Sukoharjo, Wilangan & NGA 10 & S3wa,na & S3wa \\
\hline UL 11 & Tempuran, Ngluyu & NGA 11 & Neh & S3wa,rc,eh \\
\hline UL 12 & Mojoduwur, Ngetos & NGA $12 \mathrm{~A}$ & S3wa & S3wa \\
\hline UL 13 & Bajang, Ngluyu & NGA 14 & Neh & S3wa,eh \\
\hline UL 14 & Lengkong Lor, Ngluyu & NGA $15 \mathrm{~A}$ & Neh & S3wa,nr,na,eh \\
\hline UL 15 & Bajulan, Ngetos & NGA $16 \mathrm{~A}$ & Neh & S3wa,rc,eh \\
\hline UL 16 & Kedungsoko, Sukomoro & NGA 17 & S3wa,nr & S3wa \\
\hline
\end{tabular}

Dari tabel analisis di atas, terlihat bahwa kesesuaian lahan aktual untuk tanaman bawang merah sebagian besar masuk ke dalam kelas sesuai marginal (S3) dengan faktor pembatas berupa ketersediaan air (curah hujan), ketersediaan hara dan bahaya erosi (kemiringan lereng). Sedangkan kesesuaian lahan aktual untuk tanaman bawang merah dengan kelas tidak sesuai $(\mathrm{N})$ terdapat di unit lahan $11, \mathrm{UL} 13$, UL 14, dan UL 15 dengan faktor pembatasnya 
adalah kemiringan lereng. Untuk meningkatkan kelas kesesuaian lahan naik satu kelas maka diperlukan usaha perbaikan untuk setiap faktor pembatas yang ditemukan.

Faktor curah hujan menjadi faktor pembatas untuk pertumbuhan bawang merah di seluruh unit lahan yang disurvei. Curah hujan yang sesuai untuk pertumbuhan bawang merah berkisar 350$600 \mathrm{~mm} / \mathrm{th}$. Sedangkan curah hujan di Kabupaten Nganjuk antara 1.400-1.900 mm/th dan 1.900$2.300 \mathrm{~mm} / \mathrm{th}$ sehingga masuk kelas sesuai marginal (S3). Faktor curah hujan merupakan faktor yang tidak bisa dikendalikan dalam skala mikro sehingga tidak ada usaha perbaikan yang bisa dilakukan untuk meningkatkan kelas kesesuaian lahan untuk tanaman bawang merah menjadi cukup sesuai (S2). Hanya saja pemilihan varietas bawang merah yang sesuai untuk musim kemarau dan musim hujan perlu diperhatikan.

Berdasarkan Badan Penelitian dan Pengembangan Pertanian Kementrian Pertanian, dikatakan bahwa varietas bawang merah yang sesuai untuk musim kemarau adalah varietas bima curut, sembrani, katumi dan maja, sedangkan untuk musim penghujan bisa dipilih varietas Bangkok dan Filipin. Dengan arahan pemilihan jenis varietas tersebut diharapkan produksi bawang merah di Kabupaten Nganjuk dapat ditingkatkan sehingga faktor besarnya curah hujan bisa diminimalisir.

Selain curah hujan, faktor ketersediaan oksigen dalam hal ini adalah drainase tanah juga masuk ke dalam kelas sesuai marginal (S3). Usaha perbaikan yang bisa dilakukan untuk meningkatkan kelas kesesuaian lahannya menjadi cukup sesuai (S2) adalah dengan penambahan bahan organik tanah. Dengan penambahan bahan organik tanah seperti kotoran ternak, seresah organik maupun pupuk organik dipastikan akan berpengaruh terhadap sifat fisik tanah seperti drainase tanah dan struktur tanah.

Dengan pemberian bahan organik struktur tanah menjadi lebih gembur sehingga perkembangan akar dan pertumbuhan tanaman bawang merah menjadi lebih baik. Struktur tanah ini mempengaruhi pertumbuhan tanaman bawang merah melalui pengaruhnya terhadap perkembangan akar tanaman dan proses-proses fisiologi akar tanaman seperti absorpsi hara, absorpsi air dan respirasi sehingga pembentukan umbi bawang merah menjadi lebih optimal. Di samping itu, struktur tanah juga mempengaruhi pergerakan hara, pergerakan air, sirkulasi $\mathrm{O}_{2}$ dan sirkulasi $\mathrm{CO}_{2}$ di dalam tanah (Islami \& Utomo 1995). Usaha perbaikan dengan penambahan bahan organik ini bisa diaplikasikan di unit lahan 2 di Kecamatan Bagor sehingga kondisi drainase tanahnya menjadi optimal untuk pertumbuhan bawang merah.

Selain drainase tanah, media perakaran dalam hal ini adalah tekstur tanah juga menjadi faktor pembatas pertumbuhan bawang merah di unit lahan 3 di Kecamatan Wilangan, UL 5 di Kecamatan Lengkong, dan di UL 9 di Kecamatan Pace. Tekstur tanah merupakan hasil dari proses pelapukan batuan dengan faktor-faktor yang mempengaruhinya dalam jangka waktu yang lama. Karena itulah tidak ada usaha pengelolaan lahan yang bisa dilakukan untuk mengubah tekstur tanah. Berdasarkan pengamatan di lapangan serta didukung hasil laboratorium, unit lahan 3, UL 5, dan UL 9 mempunyai tekstur tanah agak kasar sehingga masuk ke dalam kelas sesuai marginal (S3). Sedangkan tekstur tanah yang optimal untuk pertumbuhan bawang merah masuk ke dalam kategori agak halus atau sedang.

Berbeda dengan tekstur tanah yang tidak dapat diperbaiki untuk mendukung pertumbuhan bawang merah, derajat keasaman tanah $(\mathrm{pH})$ menjadi parameter kesesuaian lahan yang bisa dioptimalkan untuk pertumbuhan bawang merah. Retensi hara dalam hal ini $\mathrm{pH} \mathrm{H}_{2} \mathrm{O}$ menjadi faktor pembatas di unit lahan 16 di Kecamatan Sukomoro. $\mathrm{pH} \mathrm{H}_{2} \mathrm{O}$ di sampel unit lahan di Kecamatan Sukomoro mencapai nilai 8,2 (agak alkalis) sehingga masuk ke dalam kelas sesuai marginal (S3) dan diperlukan usaha perbaikan sehingga naik kelas menjadi cukup sesuai (S2) untuk mendukung pertumbuhan bawang merah di Kecamatan Sukomoro. Untuk menurunkan $\mathrm{pH}$ tanah dari 8.2 menjadi $\mathrm{pH}$ yang optimal untuk pertumbuhan bawang merah yaitu sekitar 6.0-7.8 adalah dengan penambahan sulfur atau belerang

Selain berpengaruh untuk menurunkan $\mathrm{pH}$ tanah, pemberian sulfur ini akan meningkatkan ketersediaan hara sulfat di dalam tanah karena ketersediaan hara sulfat di dalam tanah juga sering menjadi faktor pembatas bagi tanaman bawang merah untuk menghasilkan umbi dengan bobot dan kualitas yang baik. Selain pemberian sulfur untuk memperbaiki $\mathrm{pH}$ tanah alkali, penambahan bahan organik yang belum matang juga mampu menurunkan $\mathrm{pH}$ tanah karena selama proses dekomposisi akan melepaskan asam-asam organik yang menyebabkan menurunnya $\mathrm{pH}$ tanah.

Selain $\mathrm{pH}$ tanah, ketersediaan hara di dalam tanah juga sering menjadi faktor pembatas bagi pertumbuhan bawang merah. Kadar $\mathrm{N}$ total yang rendah, kadar $\mathrm{P}_{2} \mathrm{O}_{5}$ tersedia dan $\mathrm{K}_{2} \mathrm{O}$ tersedia menjadi unsur hara makro esensial yang harus ditingkatkan ketersediaannya di dalam tanah sehingga mampu meningkatkan produktivitas tanaman bawang merah. Ketersediaan hara di dalam tanah di beberapa unit lahan seperti UL 1 di Kecamatan Rejoso, UL 2 di Kecamatan Bagor, UL 9 di Kecamatan Pace serta UL 3, dan UL 10 di Kecamatan Wilangan masuk ke dalam kelas sesuai marginal (S3) dengan kategori rendahsangat rendah. Usaha perbaikan yang bisa dilakukan untuk meningkatkan ketersediaan hara di dalam tanah adalah dengan penambahan 
bahan organik tanah. Pemupukan anorganik dapat dilakukan tetapi kurang efisien karena sifat pupuk anorganik yang mudah mengalami penguapan saat musim kemarau, leaching (pencucian) saat musim hujan, ataupun unsur hara terikat pada mineral-mineral tanah sehingga unsur hara tidak tersedia bagi tanaman. Dengan penambahan bahan organik akan memperbaiki sifat fisik, kimia, dan biologi tanah yang dapat menunjang peningkatan produktivitas dan kualitas umbi bawang merah. Pemberian bahan organik tanah memperbaiki sifat kimia tanah seperti meningkatnya kadar C-organik tanah sehingga hara di dalam tanah menjadi tersedia bagi pertumbuhan bawang merah.

Bahaya erosi merupakan parameter lahan yang digunakan dalam kesesuaian lahan. Dalam hal ini dilihat dari kemiringan lerengnya. Kemiringan lereng menjadi salah satu faktor pembatas yang menyebabkan kesesuaian lahan aktual untuk tanaman bawang merah di unit lahan 11, UL 13, UL 14 di Kecamatan Ngluyu dan UL 15 di Kecamatan Loceret masuk ke dalam kelas tidak sesuai $(\mathrm{N})$. Karena kemiringan lereng di setiap unit lahan tersebut lebih dari $15 \%$, untuk menaikkan kelas kesesuaian lahannya diperlukan usaha perbaikan yaitu dengan pembuatan teras, penanaman searah kontur, penanaman tanaman penutup tanah, sehingga bahaya erosi bisa diminimalisir.

\subsection{Implikasi Evaluasi Lahan Terhadap Bencana Kekeringan}

Menurut Badan Koordinasi Nasional Penanggulangan Bencana (Bakornas PB) (2007) bencana kekeringan adalah hubungan antara kebutuhan air yang melebihi ketersediaan air, sedangkan Raharjo (2010) mendefinisikan kekeringan sebagai pengurangan kelembaban secara signifikan pada suatu periode tertentu yang tidak bersifat permanen. Definisi bencana kekeringan menurut BNPB yang terdapat dalam UU no 24 tentang Penanggulangan Bencana (2007) adalah ketersediaan air yang jauh di bawah kebutuhan air untuk kebutuhan hidup, untuk pertanian, kegiatan ekonomi, dan lingkungan.

Bakornas PB (2007) membedakan kekeringan berdasarkan tipenya menjadi 3 (tiga); yaitu kekeringan meteorologis, kekeringan hidrologis dan kekeringan pertanian. Kekeringan meteorologis menunjukkan curah hujan dalam satu musim yang berada di bawah normal. Kekeringan ini menjadi indikasi awal munculnya bencana di bidang pertanian. Kekeringan pertanian terjadi setelah kekeringan meteorologis, dimana kandungan air dalam tanah tidak mencukupi kebutuhan tanaman pada suatu periode tertentu dan cakupan wilayah yang luas. Kekeringan hidrologis terjadi apabila terdapat penurunan air di waduk, muka air sungai, danau, dan muka air tanah secara alami (Van Lanen, 2015).

Bencana kekeringan yang terjadi pada daerah beriklim kering akan mudah diantisipasi oleh masyarakat, tetapi kekeringan bisa saja terjadi pada daerah yang mempunyai curah hujan tinggi atau rendah (Mohammad et al., 2018). Kekeringan tersebut dapat menyebabkan kerugian pada daerah-daerah yang bergantung pada pertanian apabila tidak diantisipasi sebelumnya. Kekeringan merupakan bencana yang sangat kompleks dan mempunyai dampak yang sangat buruk terhadap manusia (Wilhite et al, 2007).

Berdasarkan hasil evaluasi status kesuburan tanah dan kesesuaian lahan untuk beberapa tanaman di Kabupaten Nganjuk, bencana kekeringan yang sering terjadi di Kabupaten Nganjuk sebenarnya bisa diminimalkan dan dihindarkan. Dalam rangka mengantisipasi kekeringan di tingkat petani, adanya penerapan pola tanam yang baik terkait perencanaan komoditas dengan berdasarkan evaluasi kesuburan tanah dan kesesuaian lahan, petani diharapkan dapat melakukan budidaya tanamannya dengan melakukan penanaman sesuai dengan kondisi iklim seperti pemilihan pola tanam padi sawah (sawah irigasi maupun tadah hujan) pada musim penghujan. Akan tetapi pada musim kemarau yang cenderung sulit air petani melakukan adaptasi terhadap kekeringan dengan cara memilih budidaya tanaman yang toleran terhadap air serta membuat irigasi pompa dalam pengelolaan airnya untuk memenuhi kebutuhan lahan pertaniannya (Gambar 2). Kondisi ini dilakukan karena sulit air pada musim kemarau dan ketersediaan air irigasi permukaan sangat terbatas karena debit air sungai yang berkurang.

Di beberapa lokasi yang lebih sulit air petani melakukan pengalolaan air dengan membuat mikro embung (Gambar 3) untuk sumberdaya pengairan bagi lahan usaha taninya. Pengelolaan sumber air dengan membuat mikro embung dirasa sangat bagus terutama pada lahan-lahan kering dataran tinggi yang memang tidak terjangkau saluran irigasi. Baik secara rekomendasi evaluasi lahan pada lahan kering maupun kecerdasan petani lokal dalam implementasi mikro embung, hal ini merupakan salahan satu antisipasi bencana kekeringan di lahan usaha taninya.

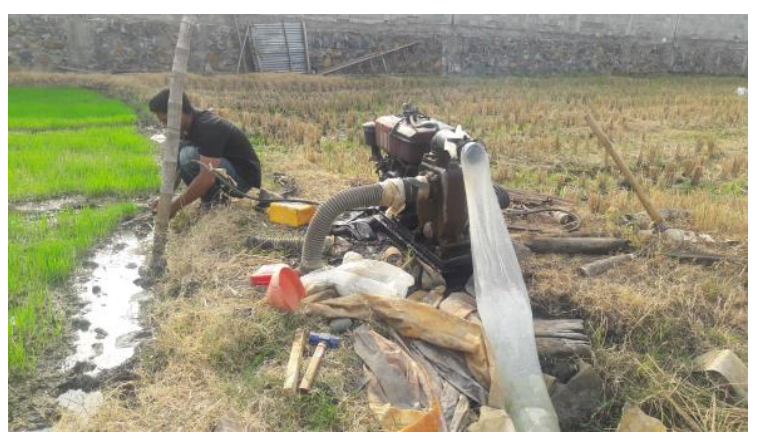


Gambar 2. Irigasi Pompa untuk Antisipasi Kekeringan

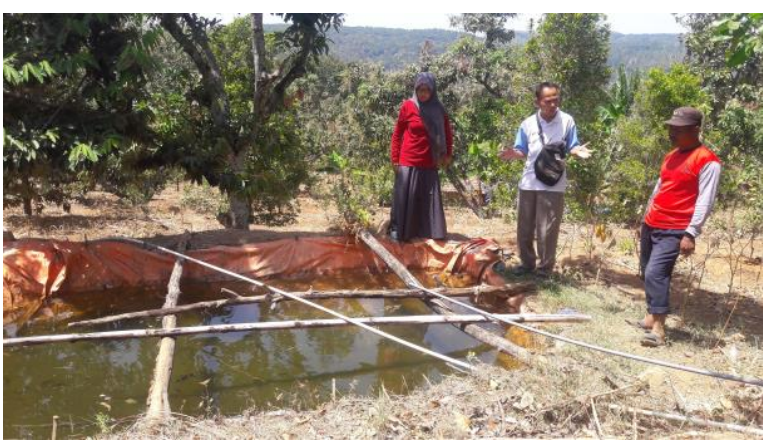

Gambar 3. Mikro Embung sebagai Upaya Mitigasi Kekeringan

Faktor-faktor yang mempengaruhi bahaya kekeringan secara berurutan adalah curah hujan, jenis penggunaan lahan, jarak ke sumber air, tekstur tanah, dan suhu permukaan tanah, dengan berbagai intervensi pengelolaan lahan seperti:

1. Pengelolaan air pada saat musim penghujan dapat dilakukan dengan pemanenan air hujan (water harvesting), baik skala rumah tangga maupun pada lahan pertanian (dengan pembangunan embung dan lain sebagainya)

2. Upaya pengolahan lahan yang minim intervensi kimia, seperti pemberian mulsa, penambahan bahan organik secara berkala, pemberian pupuk-pupuk organik. Pengelolaan lahan tersebut akan memperbaiki sifat-sifat tanah serta mempertahankan suhu permukaan tanah sehingga lebih tahan terhadap bencana kekeringan.

3. Pemilihana pola tanam yang sesuai dengan jumlah hari hujan pada daerah masing-masing.

4. Pemanfaatan penggunaan lahan sebagai wilayah konservasi.

5. Pengoptimalan sistem perairan pertanian berupa irigasi teknis pada kawasan pertanian.

6. Penataan ruang terkait pertanian dengan mempertimbangkan hasil analisis penelitian. Misalnya dibuat rencana pemusatan kegiatan pertanian pada daerah yang tergolong kurang rentan pada bencana kekeringan, sedangkan untuk daerah yang sangat rentan direkomendasikan untuk dijadikan kawasan terbangun dan tidak disarankan untuk dijadikan kawasan pertanian.

\section{KESIMPULAN DAN SARAN}

Hasil uji tanah serta kesesuaian lahan di Kabupaten Nganjuk ini dapat dipakai untuk: (1) menentukan jumlah hara yang tersedia bagi tanaman; (2) memberi peringatan kepada petani tentang bahaya-bahaya yang mungkin akan terjadi pada pertanamannya, baik bahaya defisiensi ataupun keracunan; (3) menjadi dasar penetapan dosis pupuk; (4) memberikan perkiraan produksi akibat pemakaian dosis pupuk tersebut sehingga memungkinkan dilakukannya evaluasi ekonomi; dan (5) membantu pemerintah dalam menyusun kebijaksanaan antara lain dalam hal pengelolaan air dan tanah yang berkelanjutan sehingga meminimalkan terjadinya bencana kekeringan.

Sebagai saran diperlukan analisis kesuburan tanah secara berkala setelah dilakukan upayaupaya perbaikan, sehingga akan terlihat perbedaan sebelum dan sesudah dilakukan upaya perbaikan kondisi tanah. Upaya perbaikan kondisi tanah diusahakan melalui cara yang ramah lingkungan sehingga tidak memicu penurunan kualitas tanah secara berkelanjutan.

\section{PERSANTUNAN}

Penulis mengucapkan terima kasih kepada Dr. M. llyas, S.T., M.Sc. (Direktur PTRRBBPPT), Bpk. Nur Hidayat, S.T., M.Si. (BPPT), Kepala Bappeda Kab. Nganjuk dan Bpk. Eko Wahyudi, (Bappeda Kab. Nganjuk). Ucapan terima kasih juga penulis sampaikan kepada rekan-rekan BPPT: Qoriatu Zahro, S.Si, M.Sc., Ir. Heru Sri Naryanto, M.Sc., Ir. Wisyanto, M.T. sebagai bagian dari tim yang banyak membantu selama survei di lapangan, diskusi, dan analisis data. Penelitian ini merupakan kerja sama penelitian antara PTRRB-BPPT dan Bappeda Kabupaten Nganjuk.

\section{DAFTAR PUSTAKA}

Bakornas PB. 2007. Pengenalan karakteristik bencana dan upaya mitigasinya di Indonesia. (S. Triutomo, W. Wijaya, \& M. R. Amri, Eds.). Direktorat Mitigasi, Bakornas PB.

Effendi, Syarif. 1995. IImu Tanah. PT Mediyatama Sarana Perkasa. Jakarta.

FAO. 1976. A Framework for Land Evaluation. Soil Resources Development and Conservation Service Land and Water Development Division. Fao and Agriculture Organization of The United Nations. Rome, Italy.

Hardjowigeno, S. 1981. Ilmu Tanah. Mediyatama Sarana Perkasa, Jakarta.

https://radarkediri.jawapos.com/read/2020/08/25/ 210434/kabupaten-nganjuk-siaga-daruratkekeringan-dan-karhutla

Islami, T. dan W.H. Utomo. 1995. Hubungan Tanah, Air, dan Tanaman. IKIP Semarang Press. $146 \mathrm{hlm}$.

Kabupaten Nganjuk Dalam Angka. 2020. Badan Pusat Statistik Kabupaten Nganjuk.

Khan, M. Manzoor. 1983. A Primer on Azolla Production and Utilization in Agriculture. Jointly Published by: University of the 
Philippines at Los Banos (UPLB); Philippine Council for Agriculture and Resources Research and Development (PCARRD); Southeast Asian Regional Center for Graduate Study and Research in Agriculture (SEARCA).

Mohammad, A.H., H.C. Jung, T. Odeh, C. Bhuiyan, dan H. Hussein. 2018. Understanding The Impact of Droughts in The Yarmouk Basin, Jordan: Monitoring Droughts through Meteorological and Hydrological Drought Indices. Arabian Journal of Geosciences, 11(5). https://doi.org/10.1007/s12517-018-3433-6

Poerwowidodo, 1992. Telaah Kesuburan Tanah. Penerbit Angkasa. Bandung. 126 hlm.

Purwono dan H. Purnamawati. 2007. Budidaya Delapan Jenis Tanaman Pangan Unggul. Penebar Swadaya.Jakarta

Raharjo, P.D. 2010. Teknik Penginderaan Jauh dan Sistem Informasi Geografis untuk Identifikasi Potensi Kekeringan. Makara Teknologi, 14(2), 97-105.

Rencana Tata Ruang Wilayah (RTRW). Kabupaten Nganjuk Tahun 2019-2039.

Rosmarkam, A. dan N. W. Yuwono. 2002. IImu Kesuburan Tanah. Kanisius, Yogyakarta.

Rukmana, R. 1997. Usaha Tani Jagung. Kanisius, Jogyakarta.

Statistik Daerah Kabupaten Nganjuk. 2020. Badan Pusat Statistik Kabupaten Nganjuk.

Van Lanen, H.A.J. 2015. Drought: How to be Prepared for The Hazard? In P.Quevauviller (Ed.), Hydrometeorological Hazards: Interfacing Science and Policy (1 st, Vol. 1, pp. 171-201). John Wiley \& Sons Ltd. https://doi.org/10.1002/9781118629567.ch $3 b$

Wilhite, D.A., M.D. Svoboda, dan M.J. Hayes. 2007. Understanding The Complex Impacts of Drought: A Key to Enhancing Drought Mitigation and Preparedness. Water Resource Management, 21(15122), 763-774. https://doi.org/10.1007/s11269006-9076-5 